\title{
Research on the Application of Project Arrears Based on Complete Information Repeated Game Theory
}

\author{
HongWenxia ${ }^{1}$, QianJinyu $^{1 *}$, Han Yan $^{1}$, JiaMinglei $^{1}$ \\ 1. Qingdao Technological University management school, \\ No.2, Changjiang Middle Road, Huangdao District, Qingdao, Shandong \\ *Corresponding Author:826834099@qq.com
}

\begin{abstract}
Keywords: complete information repeted game theory; project arrears; engineering guarantee Abstract:The paper first introduced the background and causes of arrears of project arrears, and got the following four reasons: unimplemented Project funds; imbalance supply and demand of the construction market; layers of subcontracting; imperfect credit system of the market. This paper talked about the implication of Game Theory in this problem, which introduced the project guarantee to start the complete information repetaed game theory between the owner and the general contractor. By introducing the principle and characteristics of game theory in detail and analyzing the advantages and disadvantages of static game and repeated game, summed up the use of the repeated game to discuss the project problem is more applicable. The paper deals with the game process and obtains the sub-game refined Nash equilibrium, obtaining the following points to solve the project arrears:reducing the total contractor's performance guarantee amount,increasing the amount of the owner's project guarantee, reducing the owner's delayed payment benefit, reducing the total contractor's delay in paying the cost of savings.
\end{abstract}

\section{Introduction}

Due to the imperfect construction of the market economy system and the imperfect social credit system, many projects have arrears in the project ${ }^{[1]}$. On the one hand, the construction industry has a large number of projects arrears, on the other hand, construction enterprises and subcontractors have arreas from materials buyers, workers wages ,national taxes and bank loans. Solving the problem can not only maintain a low cost and efficient win-win cooperation model, but also promote the active participation in the contract treaty.

\section{Project arrears related issues}

Project arrears mainly refers to the contractor after the completion of the task, in the recovery of the project, the owners can not be in accordance with the contract agreed in full or in part to pay the contractor's project. The project involves a lot of the main body, there are designers, buyers, government, subcontractors and so on. The main stakeholders discussed in this paper are the owners and the general contractors.

Reasons for Project arrears are as following shown :

(1) the project funds are not implemented

Government departments for the growth of GDP are not in place to approve a large number of "face project" and "performance project"; some real estate developers in order to expand the scale of production beyond their own financial strength ; Business in order to undertake the project, the loan for construction.

(2) imbalance supply and demand in the construction market

Adequate labor force resulting in owners in the tender and signed a contract to take advantage. The owners will impose additional provisions, and these pressure will be transferred to the grassroots construction personnel. 


\section{(3) subcontracting}

The general contractor will generally be subcontracted or subcontracted, so that the project involved more relationship is complex, resulting in the final project arrears of the phenomenon of greater probability.

(4) credit system is not perfect

On the one hand, people can not be sincere to people, on the other hand is the lack of trust between people, such as the owners do not trust the contractor, the general will be imposed on the contractor some unequal terms.

\section{Game theory and project arrears}

Full information static game is the game side to make a decision at the same time, and the two sides can fully understand the benefits, but before the decision can not know the decision-making behavior of theother. Typical examples of everyday life are "prisoner's dilemma", "stone scissors cloth" and so on.

The complete information repeated game is repeated by static or dynamic game, divided into finite and infinite repetitive games. Among them, each game is called "stage game". In each stage of the game, the participant may act at the same time, or may not act at the same time. Repeated game has three basic characteristics:

(1)There is no "material" link between each stages and previous stage does not change the structure of the latter stage game;

2) At each stage , all participants have observed the past history of the game;

3) Total benefit of the participants is the weighted average of tota stages benefits.

\section{Analysis of the Complete Information Repeated Game on the Project Arrears}

In engineering practice, the general contractor tend to pay the construction to get the favor of the owners in order to sign a construction contract. Owners and constrctions are considered short-term interests, so they do not need to consider the outcome of the game on the future. The country is to rectify the construction market, but the construction unit will not easily resort to the law to solve. In order to explain these problems, we need to introduce the idea of repeated games.

\section{Assumptions}

(1)Everyone in the environment they face will maximize their own reward.

(2)Each side have the sufficient informationof their own and the other side , including the unit quota and staff, the technical strength, the construction unit of other possible investment opportunities and the operation of funds, that is complete information.

(3)In the game analysis, the owner and contractor are able to take for their own, whether this strategy is in line with the law or not in line with the law ${ }^{[2]}$.

\section{The establishment of game model}

(1)Participants in the game: $i \in \tau, \tau=(1,2)$ (1for owner, 2 for general contractor);

(2)The strategic set of both sides: $S_{i}, i=1,2$

As the owner side has two options, one is paid on time under the contract requirements, so the general contractor has a certain amount of funds for construction arrangements to avoid the debt risk ; one is to delay payment, so it can obtain the funds originally used to pay for other purposes of investment, leaving the contractor losing profits;

As a general contractor, there are two options. One is the active construction in accordance with the schedule, to make reasonable and proper arrangements for construction according to the quality and the amount of tasks; one is negative construction, reducing human and capital investment, delaying the duration, and resulting in poor quality of the project. 
(3) The game process :

The owner and contractor go into the game stage one to one. First of all, the owners choose whether to pay on time, then the the contractor also has active construction and negative construction of corresponding options of the owners.

(4)Participants Pay on each Stage :

Participants pay of the owners and the general contractor were recorded as: $\pi_{1 t}$ and $\pi_{2 t}, t$ represents the t-stage. In order to optimize the project payment mechanism, the introduction of the project payment guarantee for owner and he performance of the guarantee for contractor is to ensure it. The two Participants Pay can be shown as the following form:

Table 1 Owner and General Contractor Payment Matrix

\begin{tabular}{|c|c|c|}
\hline Owner & Pay on time & Delay payment \\
\hline Contractor & $S, T$ & $S+m_{1}-K_{d}, T-m_{2}+K_{d}$ \\
\hline Active construction & $S_{u}+L_{d}, T+m_{3}-L_{d}$ & $S_{u}+m_{1}-K_{d}+L_{d}, T+m_{3}-m_{2}+K_{d}-L_{d}$ \\
\hline Negative construction &
\end{tabular}

Notes:S-When the quality of qualified owners income

$S_{u^{-}}$Quality unacceptable owners' income

$T$ - Owners should pay for construction

$m_{1}$ - owners delay payment of benefits

$m_{2}$ - Total contractor loan costs

$m_{3^{-}}$General contractor negative construction cost savings

$K_{d^{-}}$Owner project warranty

$L_{d^{-}}$The general contractor fulfills the guarantee

\section{Model analysis}

We first analyze the process of a game, first given the assumptions: $m_{1}-K_{d}<0, m_{3}-L_{d}>0$, according to the scribe method to obtain Nash equilibrium of the game as the following shows:

Contractors actively construction, the owners pay on time; contractors negative construction, the owners delay payment.

If we have $S_{u}+m_{1}-K_{d}+L_{d}<S$ at the t-stage, thenOwners choose to pay on time and the general contractor choose the active construction.At the $t+1$ stage, the pay for owner and the general contractor will be:

$\pi_{1}=S_{t}+(\delta S)_{t+1}+\left(\delta^{2} S\right)_{t+2}+\ldots$

$\pi_{2}=\left(S_{u}+m_{1}-K_{d}+L_{d}\right)_{t}+\left(\delta\left(S_{u}+m_{1}-K_{d}+L_{d}\right)\right)_{t+1}+\left(\delta^{2}\left(S_{u}+m_{1}-K_{d}+L_{d}\right)\right)_{t+2}+\ldots$

Repetitive game is also a dynamic game, so its equilibrium should be sub-game refined Nash equilibrium-- if the general contractor chooses the active construction in the previous stage, the owner's choice is paid on time, and latter options are also active construction. If the general contractor chooses negative construction, the options of the owners are delayed payment, and latter options for contractor are also negative construction.

To improve the game, you can make: $S>S_{u}+m_{1}-K_{d}+L_{d}, T>T+m_{3}-m_{2}+K_{d}-L_{d}$

That is to reduce the amount of the general contractor's performance guarantee, to increase the amount of the owner's project guarantee, to reduce the owner's delay in payment of benefits, to reduce the general contractor to delay the cost of payment and increase the cost of general contractor loans. 


\section{Conclusion}

This paper introduces the application of game theory in the project arrears and further analyzes the complete information repeated game. By introducing project guarantees to ensure the active implementation of the treaty of the owners and the general contractor. Only both sides have mutual trust, they can come to the win-win situation.

\section{References}

[1] Zhao, L., Li,N., Analysis on the Causes and Countermeasures of Project Arrears(2005). Journal of Coastal Enterprises and Science and Technology. 4,131-133.

[2] Tan, F., Problems in Construction Project Management(2009). Journal of Enterprise Science and Technology and Development. 8,37-39.

[3] Han, L, H., Xia, X, F., An Analysis of the Problem of Arrears in Construction Industry(2006). Journal of Building economy. 7,28-30.

[4] Sheng, B., Risk Analysis and Preventive Measures of Enterprise 's Accounts Receivable(2011). Journal of China 's economy. 6,205

[5] Huang, X, T., Credit Risk Management of Construction Project(2011). Journal of Research on Urban Construction Study. 27,232-234

[6]Liao, F., Legal Countermeasures of Local Government Debt Risk Prevention(2014). Journal of Guangdong social science. 4,227-234

[7]Zhang, P., The Present Situation and Management of Debt Operation of Local Investment and Financing Platform in China(2012). Journal of Shanghai Administration Institute. 2,95-102

Hong Wenxia, female, born in 1964, Qingdao University of Technology School of management professor, master, the main research direction: project risk, project cost, project management.

Qian Jinyu, female, born in 1994,Qingdao University of Technology master's degree, master, the main research direction: project risk, project management 